\title{
Pengembangan Metode Pengusangan Cepat Kimia pada Benih Pepaya (Carica papaya L.)
}

\section{Development of Chemical Accelerated Aging Method on Papaya Seeds (Carica papaya L.)}

\author{
Tri Ayu Pratiwi', Muhamad Rahmad Suhartanto ${ }^{1,2^{*}}$, Abdul Qadir ${ }^{1}$ \\ ${ }^{1}$ Departemen Agronomi dan Hortikultura, Fakultas Pertanian, Institut Pertanian Bogor (Bogor Agricultural University), \\ Jalan Meranti, Kampus IPB Darmaga, Bogor 16680, Indonesia. \\ ${ }^{2}$ Pusat Kajian Hortikultura Tropika, Lembaga Penelitian dan Pengabdian kepada Masyarakat Institut Pertanian Bogor, \\ Jl. Raya Pajajaran, Kampus IPB Baranangsiang, Bogor, Indonesia
}

Diterima 26 September 2018/Disetujui 22 Oktober 2018

\begin{abstract}
The quality improvement of papaya was needed in Indonesia for increasing export value and quantity. The quality of papaya could be effected on seed quality. Estimation of vigor storability was important for maintaining seed quality. Chemical accelerated aging method using ethanol have several advantages for predicting vigor storability of seeds. Seed aging (devigoration) during the aging process affected by soaking duration and aging duration. This research aims to determine the optimum soaking duration dan aging duration for chemical accelerated aging on papaya seed. This research consists of two experiments. Experiment 1 is determination of aging duration with treatment $0.1 \times 30,2 \times 30,3 \times 30$, and $4 \times 30$ minutes aging. Experiment 2 is determination of soaking duration with treatment 24, 48, 72, 96, and 120 hours soaking. The first experiment showed that aging duration 48 minutes can be reduce $50 \%$ germination of Callina papaya seed. The second experiment 2 showed that the optimum soaking duration was 48 hours. This method produced germination before aging $77.1 \%$ and after aging $38.4 \%$ with angle of regression line $38.9^{\circ}$ and moisture content about $64-66 \%$.
\end{abstract}

Keywords: callina, devigoration, ethanol, germination, soaking duration

\section{ABSTRAK}

Indonesia memerlukan peningkatan kualitas buah pepaya untuk meningkatkan kuantitas dan nilai ekspor pepaya. Kualitas buah salah satunya dipengaruhi oleh mutu benih yang digunakan. Pendugaan vigor daya simpan diperlukan untuk mempertahankan mutu benih. Metode pengusangan cepat kimia menggunakan etanol memiliki beberapa keunggulan dalam menduga vigor daya simpan benih. Kemunduran benih (devigorasi) selama proses pengusangan dipengaruhi oleh waktu pelembaban dan waktu pengusangan. Penelitian ini bertujuan untuk menentukan waktu pengusangan dan waktu pelembaban optimum untuk pengusangan cepat kimia pada benih pepaya. Penelitian ini terdiri atas dua percobaan. Percobaan 1 adalah penentuan waktu pengusangan dengan perlakuan 0, 1x30, 2x30, 3x30, dan 4x30 menit pengusangan. Percobaan 2 adalah penentuan waktu pelembaban dengan perlakuan 24, 48, 72, 96, dan 120 jam pelembaban. Percobaan 1 menunjukkan bahwa waktu pengusangan 48 menit dapat menurunkan 50\% daya berkecambah sehingga dihasilkan waktu pengusangan untuk Percobaan 2, yaitu 0, 1x12, 2x12, 3x12, dan 4x12 menit. Percobaan 2 menunjukkan bahwa waktu pelembaban optimum adalah 48 jam. Metode ini menghasilkan daya berkecambah sebelum pengusangan $77.1 \%$ dan setelah pengusangan $38.4 \%$ dengan sudut kemiringan garis regresi $38.9^{\circ}$ serta kadar air berkisar $64-66 \%$.

Kata kunci: callina, daya berkecambah, devigorasi, etanol, waktu pelembaban

\section{PENDAHULUAN}

Data FAOSTAT (2015) tahun 2009-2013 menunjukan bahwa Indonesia memiliki produktivitas pepaya lebih tinggi dari negara-negara di Asia Tenggara, tetapi memiliki kuantitas dan nilai ekspor pepaya yang jauh lebih rendah. Salah satu penyebabnya adalah kualitas pepaya negara

\footnotetext{
*Penulis untuk korespondensi. e-mail: tantosuhartanto63@gmail. com
}

lain lebih baik dari Indonesia. Kualitas tersebut berkaitan dengan mutu benih. Kemampuan benih mempertahankan mutu bergantung pada vigor daya simpannya. Pendugaan vigor daya simpan benih dapat dilakukan dengan metode penyimpanan alami dan metode pengusangan cepat (accelerated aging methods, AAM).

Metode pengusangan cepat dapat dilakukan baik secara fisik maupun kimia. Beberapa penelitian menunjukkan metode pengusangan cepat kimia menghasilkan laju 
devigorasi lebih cepat dibandingkan dengan metode pengusangan cepat secara fisik (Badriah, 2012; Belo dan Suwarno, 2012; Terryana, 2013). Pengusangan cepat kimia menggunakan etanol atau metanol untuk menstimulasi terjadinya kemunduran benih atau devigorasi. Penelitian sebelumnya menunjukkan bahwa penggunaan etanol lebih efektif untuk mengusangkan benih (Addai dan Kantanka, 2006; Agustin, 2010). Kemunduran benih yang terjadi selama proses pengusangan dipengaruhi oleh waktu pelembapan dan waktu pengusangan. Pelembaban menstimulasi reaksi metabolisme benih yang akan meningkatkan efektivitas deraan etanol. Peningkatan waktu pengusangan meningkatkan jumlah etanol dalam benih akan mempercepat proses kemunduran benih (Imaniar, 2012).

Pengusangan cepat pada benih pepaya belum pernah dilakukan. Penelitian ini bertujuan untuk menentukan waktu pengusangan dan waktu pelembaban yang sesuai untuk pengusangan cepat kimia pada benih pepaya. Metode pengusangan cepat benih pepaya yang efektif, cepat, mudah, dan akurat diharapkan dapat membantu produsen, ilmuwan, dan analis benih dalam menduga vigor daya simpan.

\section{BAHAN DAN METODE}

Penelitian ini dilaksanakan di Laboratorium Ilmu dan Teknologi Benih serta rumah kaca Kebun Percobaan Leuwikopo, Departemen Agronomi dan Hortikultura IPB pada bulan Januari-Mei 2016. Penelitian ini terdiri atas dua percobaan. Percobaan 1 bertujuan untuk mempelajari waktu pengusangan optimum. Faktornya adalah waktu pengusangan yang terdiri atas lima taraf, yaitu $0.1 \times 30$, $2 \times 30,3 \times 30$, dan $4 \times 30$ menit. Percobaan 2 bertujuan untuk mempelajari waktu pelembaban optimum. Faktornya adalah waktu pelembaban yang terdiri atas lima taraf, yaitu 24, 48, 72, 96, dan 120 jam. Percobaan 2 menentukan lama pelembaban dari pengusangan yang menyebabkan daya berkecambah turun $50 \%$. Waktu pengusangan untuk menurunkan daya berkecambah hingga 50\% disebut dengan $\mathrm{P}_{50} . \mathrm{P}_{50}$ didapatkan dari percobaan $1 . \mathrm{P}_{50}$ tersebut dibagi menjadi lima waktu pengusangan.

Prosedur percobaan 1 dan percobaan 2 terdiri atas penyiapan lot benih, pelembaban, dan pengusangan. Benih diekstraksi kemudian dibersihkan dari sarcotesta. Benih tersebut dikeringkan hingga kadar airnya 6-9\% (Wulandari, 2009). Benih hampa dipisahkan menggunakan blower. Benih pada setiap taraf perlakuan dilembapkan diantara kertas buram. Benih yang telah dilembabkan dimasukkan ke dalam APC IPB 77-1 MM. Setiap pengusangan membutuhkan 50 $\mathrm{ml}$ etanol $96 \%$.

Penetapan kadar air dilakukan pada akhir waktu pelembaban. Benih dikecambahkan di dalam boks plastik berisi pasir yang telah disterilisasi (direbus atau diberi Dithane $2 \mathrm{~g} \mathrm{~L}^{-1}$ air). Jumlah benih yang dikecambahkan adalah 50 butir per satuan percobaan. Penyiraman dilakukan setiap hari menggunakan aquades. Pengamatan meliputi indeks vigor, daya berkecambah, dan potensi tumbuh maksimumnya.

\section{HASIL DAN PEMBAHASAN}

\section{Percobaan 1}

Pengujian viabilitas dan vigor benih menggunakan metode pengusangan cepat kimia salah satunya dipengaruhi waktu pengusangan. Belo dan Suwarno (2012) menyatakan bahwa lama waktu pengusangan berkorelasi negatif pada viabilitas benih. Pengaruh waktu pengusangan pada benih pepaya Callina dapat dilihat pada Tabel 1. Hasil pada Tabel 1 menunjukkan bahwa waktu pengusangan berpengaruh sangat nyata terhadap peubah indeks vigor, daya berkecambah, dan potensi tumbuh maksimum tetapi, tidak berpengaruh nyata terhadap peubah kadar air. Nilai tengah dari setiap peubah terhadap pengaruh waktu pengusangan menunjukkan adanya tren penurunan indeks vigor, daya berkecambah, dan potensi tumbuh maksimum. Hasil uji nilai tengah atau DMRT pada taraf $\alpha=5 \%$ menunjukan bahwa benih yang tidak diusangkan memiliki nilai tertinggi. Pengusangan cepat kimia selama 1x30 menit dan 2x30 menit tidak berbeda nyata pada peubah indeks vigor, tetapi berbeda nyata lebih tinggi pada peubah daya berkecambah dan potensi tumbuh maksimum. Tabel 1 menunjukkan bahwa pengusangan cepat kimia selama $3 \times 30$ menit dan 4x30 menit memiliki nilai terendah dengan menurunkan viabilitas dan vigor benih hingga $0 \%$.

Penurunan viabilitas dan vigor benih akibat pengusangan cepat sebaiknya terjadi secara gradual. Waktu pengusangan yang diperlukan berbeda-beda untuk setiap tingkat daya berkecambah yang ingin dihasilkan dan benih yang digunakan. Penurunan daya berkecambah dibatasi sebanyak 50\% untuk mendapatkan waktu pengusangan yang optimum untuk benih pepaya Callina.

Tabel 1. Pengaruh waktu pengusangan cepat kimia pada benih pepaya Callina terhadap peubah kadar air (KA), indeks vigor (IV), daya berkecambah (DB), dan potensi tumbuh maksimum (PTM)

\begin{tabular}{ccccc}
\hline $\begin{array}{c}\text { Waktu pengusangan } \\
\text { (menit) }\end{array}$ & \multicolumn{4}{c}{ Peubah } \\
\cline { 2 - 5 } & $\mathrm{KA}(\%)$ & $\mathrm{IV}^{\mathrm{A}}(\%)$ & $\mathrm{DB}^{\mathrm{A}}(\%) \mathrm{PTM}^{\mathrm{B}}(\%)$ \\
\hline 0 & 54.5 & $77.2^{\mathrm{a}}$ & $82.2^{\mathrm{a}}$ & $85.8^{\mathrm{a}}$ \\
$1 \times 30$ & 51.5 & $42.8^{\mathrm{b}}$ & $78.1^{\mathrm{a}}$ & $79.7^{\mathrm{a}}$ \\
$2 \times 30$ & 51.4 & $39.0^{\mathrm{b}}$ & $54.9^{\mathrm{b}}$ & $58.4^{\mathrm{b}}$ \\
$3 \times 30$ & 49.8 & $0.0^{\mathrm{c}}$ & $0.0^{\mathrm{c}}$ & $0.0^{\mathrm{c}}$ \\
$4 \times 30$ & 49.4 & $0.0^{\mathrm{c}}$ & $0.0^{\mathrm{c}}$ & $0.0^{\mathrm{c}}$ \\
$\mathrm{Pr}>\mathrm{F}$ & $0.1066^{\text {th }}<.0001^{* *}<.0001^{* *}$ & $<.0001^{* *}$ \\
$\mathrm{KK}(\%)$ & 40.971 & 6.2472 & 3.3515 & 9.4974 \\
\hline
\end{tabular}

Keterangan: Angka yang diikuti oleh huruf yang diikuti huruf berbeda pada kolom yang sama berbeda nyata berdasarkan hasil DMRT pada taraf $\alpha=5 \%$. tn $=$ tidak berpengaruh nyata pada taraf $\alpha=5 \%$. ** = berpengaruh sangat nyata pada taraf $\alpha=5 \% . A=$ data ditransformasi ke $\ln (\mathrm{x}+1) . \mathrm{B}=$ data ditransformasi $\mathrm{ke} \arcsin \sqrt{\mathrm{x}}$ 
Perkiraan waktu pengusangan yang mengakibatkan daya berkecambah menurun hingga 50\% disebut juga dengan istilah $\mathrm{P}_{50} . \mathrm{P}_{50}$ ditentukan berdasarkan grafik yang dihasilkan dari probit analysis (Gambar 1). Persamaan grafik probit analysis yang dihasilkan adalah $\mathrm{Y}=92.73-$ $0.5359 \mathrm{X}-0.01113 \mathrm{X}^{2}+0.000077 \mathrm{X}^{3}$. Gambar 1 menunjukkan bahwa $\mathrm{P}_{50}$ benih pepaya Callina adalah 48 menit. Taraf waktu pengusangan perlu dipersempit agar menghasilkan penurunan yang gradual.

\section{Percobaan 2}

Pelembaban merupakan salah satu faktor yang mempengaruhi proses pengusangan. Pelembaban akan meningkatkan kadar air benih yang akan menginisiasi kembali proses metabolisme dalam benih. Proses metabolisme membutuhkan energi. Energi dapat dihasilkan melalui proses respirasi baik secara aerob maupun anaerob. Respirasi aerob belum dapat dilakukan karena aktivasi mitokondria memerlukan waktu. Benih melakukan respirasi anaerob hingga mitokondria kembali fungsional. Menurut Kodde et al. (2011), respirasi ini menghasilkan etanol yang dapat menurunkan integritas membran. Penurunan integritas membran tersebut akan meningkatkan efektivitas deraan etanol.

Percobaan ini menentukan lama waktu pelembaban dari pengusangan selama $0.1 \times 12,2 \times 12,3 \times 12$, dan $4 \times 12$ menit. Waktu pengusangan tersebut ditentukan berdasarkan hasil percobaan 1 . Waktu pelembaban optimum ditentukan berdasarkan pengaruh dan korelasi waktu pengusangan terhadap indeks vigor, daya berkecambah, potensi tumbuh maksimum, dan kadar air. Waktu pelembaban optimum menyebabkan waktu pengusangan berkorelasi dan berpengaruh nyata terhadap nilai indeks vigor, daya berkecambah, potensi tumbuh maksimum, dan kadar air benih.

Analisis datamenggunakananalisisregresidankorelasi. Waktu pelembapan optimum ditentukan berdasarkan nilai $\mathrm{R}^{2}$ mendekati 1 dan $\mathrm{r}$ mendekati 1 atau -1 dengan $p$-value mendekati 0 . Nilai koefisien determinasi $\left(\mathrm{R}^{2}\right)$ mendekati 1 berarti keragaman peubah viabilitas dan vigor benih sebagian besar dapat digambarkan oleh keragaman waktu

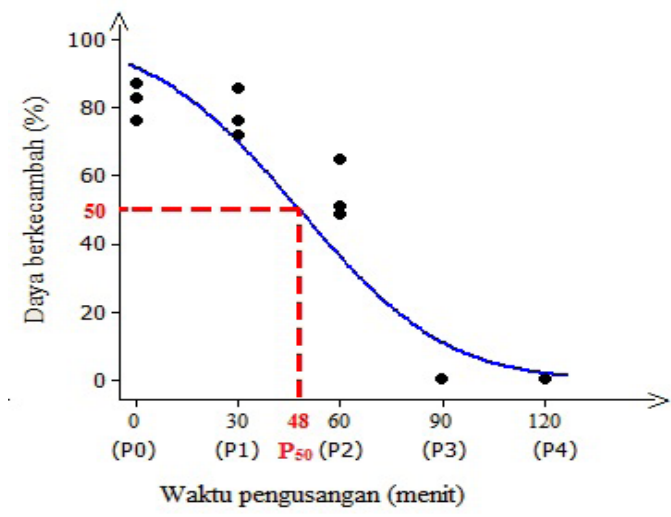

Gambar 1. Penurunan viabilitas dan vigor benih akibat pengusangan cepat pengusangan. Nilai koefisien korelasi (r) mendekati 1 atau -1 berarti nilai peubah viabilitas dan vigor benih semakin berhubungan erat dengan waktu pengusangan. Tanda $(+)$ atau (-) menentukan arah hubungannya, yaitu berkorelasi positif atau negatif. Tanda tersebut terlihat dari koefisien kemiringan atau slope $(\beta)$ dalam persamaan regresi. $P$-value mendekati 0 berarti persamaan diterima atau $\mathrm{X}$ berpengaruh terhadap Y. Hasil analisis regresi dan korelasi dapat dilihat pada Tabel 2.

Tabel 2 menunjukkan bahwa peubah indeks vigor, potensi tumbuh maksimum, dan kadar air pada pelembaban 48 jam serta daya berkecambah pada pelembaban 96 jam memiliki nilai $\mathrm{R}^{2}$ dan $\mathrm{r}$ terbesar. Nilai $\mathrm{R}^{2}$ menunjukkan bahwa waktu pengusangan mempengaruhi indeks vigor sebanyak $73.1 \%$, daya berkecambah sebanyak $79.6 \%$, potensi tumbuh maksimum sebanyak $68 \%$, dan kadar air sebanyak $57.6 \%$. Nilai $\mathrm{r}$ menunjukkan bahwa waktu pengusangan berhubungan erat dengan indeks vigor sebanyak $85.5 \%$, daya berkecambah sebanyak $89.2 \%$, potensi tumbuh maksimum sebanyak $82.6 \%$, dan kadar air sebanyak $75.9 \%$. Koefisien kemiringan atau slope $(\beta)$ menunjukkan waktu pengusangan berkorelasi negatif terhadap indeks vigor, daya berkecambah, potensi tumbuh maksimum, dan kadar air yang nilainya akan semakin menurun semakin lama pengusangan. Nilai p-value menunjukkan bahwa koefisien $\alpha$ dan $\beta$ dalam persamaan regresi berpengaruh signifikan, yang berarti bahwa persamaan regresi tersebut diterima. Persamaan regresi tersebut dapat digunakan untuk menduga nilai indeks vigor, daya berkecambah, potensi tumbuh maksimum, dan kadar airnya.

Indeks vigor dan daya berkecambah dijadikan tolak ukur dalam pemilihan waktu pelembapan. Hasil dalam Tabel 2 menunjukkan bahwa respon terbaik indeks vigor dan daya berkecambah terjadi pada waktu pelembaban yang berbeda. Indeks vigor memberikan respon terbaik terhadap waktu pengusangan pada saat dilembabakan selama 48 jam sedangkan daya berkecambah memberikan respon terbaik terhadap waktu pengusangan pada saat dilembabkan selama 96 jam. Respon peubah lainnya juga perlu dilihat karena ada perbedaan tersebut. Potensi tumbuh maksimum dan kadar air memberikan respon terbaik terhadap waktu pengusangan pada saat dilembabkan selama 48 jam. Benih sudah mengalami radicle protrussion pada pelembaban 96 dan 120 jam. Kemunculan radikula menembus endotesta benih pepaya menandakan dimulainya awal fase perkecambahan. Hal-hal tersebut menjadi alasan waktu pelembaban 48 jam dinilai lebih baik dibandingkan waktu pelembapan 96 jam.

Penurunan indeks vigor, daya berkecambah, potensi tumbuh maksimum, dan kadar air dapat dilihat dari garis regresi yang dihasilkan. Laju penurunan viabilitas dan vigor berbeda-beda pada setiap waktu pelembaban. Pengaruh waktu pengusangan cepat kimia pada beberapa tingkat kelembapan dalam bentuk garis regresi dapat dilihat di Gambar 2. Hasil analisis regresi dan korelasi pada Tabel 2 dan Gambar 2 menunjukkan pelembaban 48 jam menyebabkan waktu pengusangan berkorelasi negatif dan berpengaruh sangat nyata terhadap peubah indeks vigor, daya berkecambah, potensi tumbuh maksimum, dan kadar 
air. Hasil tersebut sesuai dengan hasil penelitian sebelumnya. Imaniar (2012) menyatakan bahwa peningkatan lama waktu pengusangan akan meningkatkan kandungan etanol dan menurunkan kadar air dalam benih. Badriah (2012) juga menyatakan bahwa terdapat keeratan yang sangat kuat antara lama waktu pengusangan dengan peubah indeks vigor, daya berkecambah, dan potensi tumbuh maksimum.

Kadar air, indeks vigor, daya berkecambah, dan potensi tumbuh maksimum memiliki laju penurunan yang berbeda-beda pada setiap waktu pelembaban. Penentuan laju penurunan tersebut selain menggunakan kemiringan koefisien kemiringan atau slope $(\beta)$ dalam persamaan regresi dapat juga secara praktis menggunakan nilai $\Delta y \operatorname{dan} \theta$. Nilai $\Delta \mathrm{y}$ merupakan selisih nilai y pada saat $\mathrm{x}=0$ dan $\mathrm{x}=48$. Nilai $\theta$ merupakan sudut kemiringan garis regresi. Nilai $\Delta y \operatorname{dan} \theta$ tersebut dapat dilihat dalam Tabel 3.

Nilai $\Delta y$ dan $\theta$ pada Tabel 3 tidak digunakan sebagai tolak ukur pemilihan waktu pelembaban optimum. Nilai tersebut menggambarkan kondisi yang diperoleh dari metode pegusangan cepat dengan pelembapan 48 jam.
Daya berkecambah awal $77.1 \%$ dan daya berkecambah setelah 48 menit pengusangan $38.4 \%$ dengan selisih $(\Delta y)$ $38.7 \%$. Kadar air awal 66.2\% dan kadar air setelah 48 menit pengusangan $64.5 \%$ dengan selisih $(\Delta y) 1.7 \%$. Garis regresi waktu pelembapan 48 jam memiliki sudut kemiringan $(\theta)$ sebesar $38.9^{\circ}$ untuk daya berkecambah dan $2.0^{\circ}$ untuk kadar air.

Laju penurunan viabilitas dan vigor dipengaruhi oleh proses metabolisme dalam benih. Perbedaan waktu pelembaban menimbulkan perbedaan proses metabolisme dalam benih. Proses tersebut dimulai dari fase aktivasi, fase pertumbuhan embrio (pembelahan sel, pemanjangan sel, dan pembesaran sel), hingga fase perkecambahan. Laju penurunan yang terjadi antara waktu pelembaban yang satu dengan yang lain berbeda.

Benih masih dalam fase aktivasi pada pelembaban 24 jam. Inisiasi proses metabolisme masih berlangsung sehingga benih masih memiliki cukup cadangan makanan sebagai energi untuk pertumbuhan embrio. Aktivitas metabolisme yang meningkat menyebakan berkurangnya

Tabel 2. Pengaruh waktu pelembaban sebelum pengusangan cepat kimia pada benih pepaya Callina

\begin{tabular}{|c|c|c|c|c|}
\hline Waktu pelembaban (jam) & Persamaan regresi & $\mathrm{R}^{2}$ & $\mathrm{r}$ & $P$-value \\
\hline \multicolumn{5}{|c|}{ Indeks vigor } \\
\hline 24 & $\mathrm{Y}=35.1-0.73300 \mathrm{X}$ & 0.53 & -0.728 & $0.002^{* *}$ \\
\hline 48 & $Y=41.1-0.88900 X$ & 0.731 & -0.855 & $0.000^{* *}$ \\
\hline 72 & $Y=54.7-1.00000 X$ & 0.585 & -0.765 & $0.001^{* *}$ \\
\hline 96 & $Y=38.5-0.60000 X$ & 0.396 & -0.629 & $0.012^{*}$ \\
\hline 120 & $Y=35.3-0.42800 X$ & 0.281 & -0.53 & $0.042^{*}$ \\
\hline \multicolumn{5}{|c|}{ Daya berkecambah } \\
\hline 24 & $Y=73.6-0.67800 X$ & 0.516 & -0.718 & $0.003^{* *}$ \\
\hline 48 & $Y=77.1-0.80600 X$ & 0.483 & -0.695 & $0.004^{* *}$ \\
\hline 72 & $Y=74.4-1.06000 X$ & 0.504 & -0.71 & $0.003^{* *}$ \\
\hline 96 & $Y=65.1-1.19000 X$ & 0.796 & -0.892 & $0.000^{* *}$ \\
\hline 120 & $Y=76.7-0.76700 X$ & 0.534 & -0.731 & $0.002^{* *}$ \\
\hline \multicolumn{5}{|c|}{ Potensi tumbuh maksimum } \\
\hline 24 & $\mathrm{Y}=81.3-0.18300 \mathrm{X}$ & 0.249 & 0.499 & $0.058^{\text {th }}$ \\
\hline 48 & $Y=83.3-0.45600 X$ & 0.683 & 0.826 & $0.000^{* *}$ \\
\hline 72 & $Y=87.2-0.68400 X$ & 0.4 & 0.632 & $0.011^{*}$ \\
\hline 96 & $Y=83.5-0.69400 X$ & 0.569 & 0.754 & $0.001^{* *}$ \\
\hline 120 & $Y=88.0-0.45000 X$ & 0.438 & 0.662 & $0.007^{* *}$ \\
\hline \multicolumn{5}{|c|}{ Kadar air } \\
\hline 24 & $Y=64.5-0.11000 X$ & 0.307 & -0.554 & $0.032^{*}$ \\
\hline 48 & $Y=66.2-0.03570 X$ & 0.576 & -0.759 & $0.001^{* *}$ \\
\hline 72 & $Y=66.1-0.02050 X$ & 0.389 & -0.624 & $0.013^{*}$ \\
\hline 96 & $Y=65.5-0.02100 X$ & 0.432 & -0.657 & $0.008^{* *}$ \\
\hline 120 & $Y=65.9-0.06760 X$ & 0.512 & -0.716 & $0.003^{* *}$ \\
\hline
\end{tabular}

Keterangan: $\mathrm{Y}=$ peubah viabilitas dan vigor benih, $\mathrm{x}=$ waktu pengusangan benih, $*=$ berpengaruh nyata pada taraf $\alpha=5 \%$, $* *$ = berpengaruh sangat nyata pada taraf $\alpha=5 \%, \mathrm{tn}=$ tidak berpengaruh nyata pada taraf $\alpha=5 \%$ 

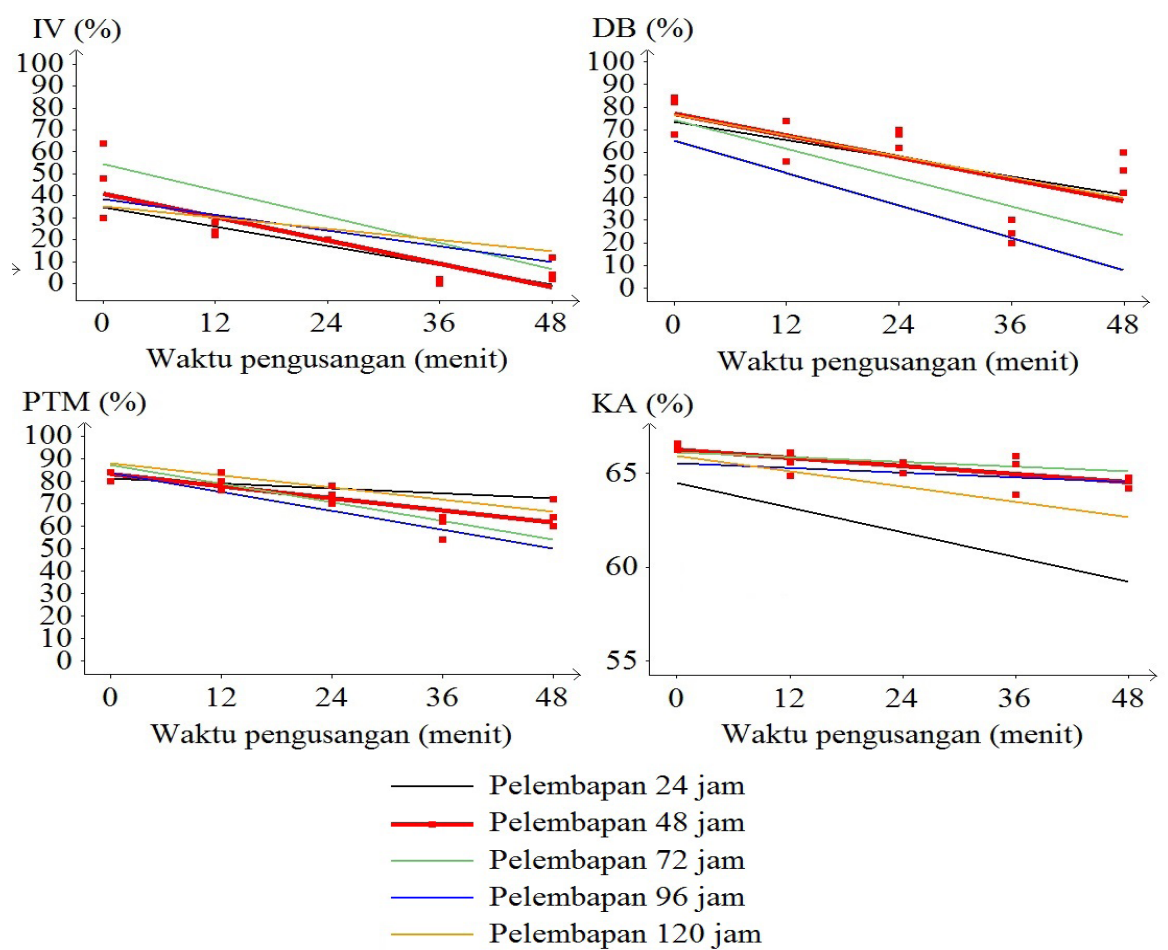

Tabel 3. Laju penurunan ( $\Delta \mathrm{Y}$ dan $\gamma)$ nilai peubah kadar air (KA), indeks vigor (IV), daya berkecambah (DB), potensi tumbuh maksimum (PTM) benih pepaya Callina pada beberapa waktu pelembaban

\begin{tabular}{cccccc}
\hline \multirow{2}{*}{ Peubah } & \multicolumn{5}{c}{ Waktu pelembaban (jam) } \\
\cline { 2 - 6 } & 24 & 48 & 72 & 96 & 120 \\
\hline \multicolumn{5}{c}{$\Delta \mathrm{y}(\%)$} \\
\hline KA & 5.3 & 1.7 & 1.0 & 1.0 & 3.2 \\
IV & 35.2 & 42.7 & 48.0 & 28.8 & 20.5 \\
DB & 32.5 & 38.7 & 50.9 & 57.1 & 36.8 \\
PTM & 8.8 & 21.9 & 32.8 & 33.3 & 21.6 \\
\hline & \multicolumn{5}{c}{$\theta\left({ }^{\circ}\right)$} \\
KA & 6.2 & 2.0 & 1.2 & 1.2 & 3.9 \\
IV & 36.2 & 41.6 & 45.0 & 31.0 & 23.2 \\
DB & 34.1 & 38.9 & 46.7 & 49.9 & 37.5 \\
PTM & 10.4 & 24.5 & 34.4 & 34.7 & 24.2 \\
\hline
\end{tabular}

Keterangan : $\Delta y=$ selisih laju penurunan, $\theta=$ sudut kemiringan

cadangan makanan benih. Embrio menjadi kekurangan energi untuk tumbuh menjadi kecambah normal. Laju penurunan bertambah cepat hingga waktu pelembaban 72 jam untuk peubah indeks vigor dan waktu pelembaban 96 jam untuk peubah daya berkecambah, dan potensi tumbuh maksimum. Laju penurunan kadar air salah satunya dipengaruhi oleh komposisi air bebas dan air terikat dalam benih. Reedy dan Knapp (1990) menyatakan bahwa kadar air benih dipengaruhi oleh banyak variabel, diantaranya suhu, imbibisi, substrat, air bebas, ukuran benih, dan kekerasan benih. Air bebas merupakan air yang dapat diuapkan pada proses penetapan kadar air. Air terikat merupakan air yang tidak dapat diuapkan pada proses penetapan kadar air karena memiliki ikatan kimia yanga hanya dapat dilepas melalui pemanasan suhu tinggi tinggi.

Benih pada fase aktivasi akan terus meningkatkan kadar airnya hingga titik maksimum. Tingkat kadar air maksimum pada fase aktivasi dinamakan tingkat kadar air kritis. Benih pada fase ini memiliki banyak air bebas. Air bebas dapat membentuk ikatan hidrogen dengan etanol hasil respirasi anaerob dan penderaan. Semakin lama pengusangan, ikatan hidrogen yang terbentuk akan semakin banyak. Hal ini menyebabkan menurunnya jumlah air bebas dan berat air hilang. Kadar air benih terus menurun seiring bertambahnya waktu pengusangan. Puncak laju penurunan kadar air terjadi pada fase ini.

Kadar air kritis diduga tercapai pada pelembaban 48 jam karena kadar air awal sebelum pengusangannya tertinggi dibanding yang lain. Kadar air tidak lagi bertambah hingga benih masuk pada fase pertumbuhan embrio. Aktivitas metabolisme seperti sintesis protein akan meningkat setelah kadar air kritis tercapai. Jumlah molekul air yang terikat pada protein meningkat. Air terikat sangat kuat dalam bentuk protein sehingga berat air hilang menjadi semakin sedikit. Laju penurunan kadar air terus melambat hingga pelembapan $72 \mathrm{jam}$.

Benih mulai memasuki fase perkecambahan yang ditandai dengan radicle protrussion pada pelembaban 96 dan 120 jam. Laju penurunan indeks vigor terus melambat dari pelembaban 96 jam hingga pelembaban 120 jam. Laju penurunan daya berkecambah dan potensi tumbuh 
maksimum mencapai puncaknya pada pelembaban 96 jam, tetapi kembali melambat pada pelembaban 120 jam. Laju penurunan yang melambat tersebut mungkin dikarenakan efektifitas deraan etanol berbeda pada benih yang sudah memasuki fase perkecambahan. Laju penurunan kadar air bertambah cepat dari pelembapan 96 jam hingga pelembaban 120 jam. Kadar air kembali meningkat karena peningkatan respirasi akan terjadi pada awal fase perkecambahan hingga terbentuk kecambah normal.

\section{KESIMPULAN}

Waktu pengusangan 48 menit dapat menurunkan $50 \%$ daya berkecambah benih pepaya Callina. Waktu pengusangan tersebut ditentukan dari persamaan $\mathrm{Y}=92.73-$ 0.5359X-0.01113X2+0.000077X3. Waktu pelembaban optimum untuk pengusangan cepat kimia benih pepaya Callina adalah 48 jam dengan waktu pengusangan $0.1 \times 12$, $2 \times 12$, 3x12, dan 4x12 menit. Daya berkecambah sebelum pengusangan $77.1 \%$ dan setelah pengusangan $38.4 \%$ dengan selisih ( $\Delta$ y) 38.7\%. Kadar air sebelum pengusangan $66.2 \%$ dan setelah pengusangan $64.5 \%$ dengan selisih $(\Delta y) \quad 1.7 \%$. Garis regresi waktu pelembapan 48 jam memiliki sudut kemiringan $(\theta)$ sebesar $38.9^{\circ}$ untuk daya berkecambah dan $2.0^{\circ}$ untuk kadar air.

\section{DAFTAR PUSTAKA}

Addai, L.K., O.S. Kantanka. 2006. Evaluation of screening methods for improved storability of soybean seed international. Journal of Botany 2(2):152-155.

Agustin, H. 2010. Hubungan antara kandungan antosianin dengan ketahanan benih kedelai (Glycine max L. Merr) terhadap pengusangan cepat beberapa varietas kedelai. Skripsi. Fakultas Pertanian. Institut Pertanian Bogor. Bogor.
Badriah, R. 2012. Pemanfaatan alat pengusangan cepat (apc) tipe IPB 77-1 MM untuk pendugaan vigor daya simpan benih jagung (Zea mays L.). Skripsi. Fakultas Pertanian. Institut Pertanian Bogor. Bogor.

Belo, S.M., F.C. Suwarno. 2012. Penurunan viabilitas benih padi (Oryza sativa L.) melalui beberapa metode pengusangan cepat. J. Agron. Indonesia 40(1):29-35.

[FAOSTAT] Food and Agriculture Organization of The United Nations Statistics Division. 2015. Compare Data.http://faostat3.fao.org/compare/E[31 Desember 2015].

Imaniar, A. 2012. Pemanfaatan alat pengusangan cepat (APC) IPB 77-1 MM untuk pendugaan vigor daya simpan benih kedelai (Glycine $\max$ (L.) Merr.). Skripsi. Fakultas Pertanian. Institut Pertanian Bogor. Bogor.

Kodde, J., W.T. Buckley, C.C. Groot, M. Retiere, A.M.V. Zamora, S.P.C. Groot. 2011. A Fast Ethanol Assay to Detect Seed Deterioration. Seed Science Research. Cambridge University Press, England, UK.

Reedy, M.E., A.D. Knapp. 1990. Ethanol evolution during the early germination of artificially aged soybean seeds. Journal of Seed Technology. 14(2):77-82.

Terryana, R.T. 2013. Pemanfaatan mesin pengusangan cepat (MPC) IPB 77-1 MM untuk penapisan vigor daya simpan benih kedelai (Glycine max L.). Tesis. Sekolah Pascasarjana. Institut Pertanian Bogor. Bogor.

Wulandari, R.R. 2009. Pengujian sifat benih pepaya (Carica papaya L.) dengan penyimpanan suhu dingin. Skripsi. Fakultas Pertanian. Institut Pertanian Bogor. Bogor. 